\title{
EFEKTIVITAS PEMBAGIAN HARTA GONO - GINI PASCA PERCERAIAN DALAM PERSFEKTIF YURIDIS SOSIOLOGI
}

\author{
Ongky Alexander
}

STAI Bumi Silampari Lubuklinggau

ongkynhu@gmail.com

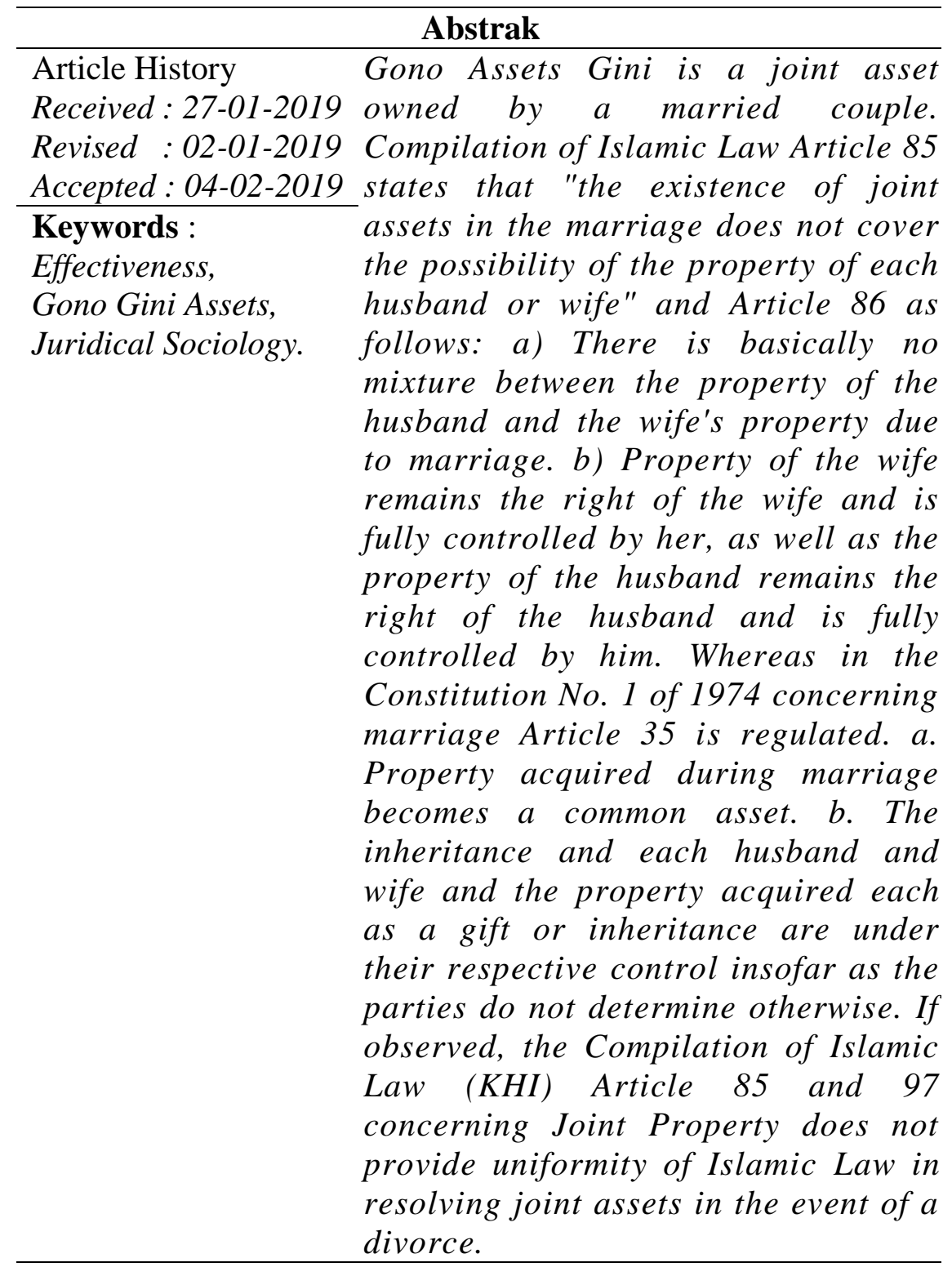




\section{Pendahuluan}

Tujuan Perkawinan untuk membentuk keluarga yang bahagia dan kekal. Akan tetapi perkawinan dalam membentuk keluarga terkadang tidak berjalan sesuai dengan rencana. Untuk Membangun rumah tangga memang tidak mudah perlu persiapan lahir dan batin. masalah ekonomi merupakan tolak ukur untuk membina rumah tangga, apabila rumah tangga mengalami kondisi yang tidak stabil, maka timbulya perselisihan dan pertengakaran. Perkawinan adalah ikatan lahir batin antara seorang pria dan seorang wanita sebagai suami istri dengan tujuan membentuk keluarga atau rumah tangga yang bahagia dan kekal berdasarkan Ketuhanan Yang Maha Esa. Akan tetapi, apabila pasangan suami istri tidak saling memahami satu sama lainnya tidak agar terwujudnya rumah tangga yang bahagia dan sakinah.(UU Perkawinan No 1 Tahun 1974 Tentang Harta Bersama)

Perkawinan berdasarkan Islam terkandung tiga aspek atau segi yaitu segi Hukum, segi sosial dan segi keagamaan. Dari segi Hukum yaitu perkawinan adalah suatu perjanjian bukan suatu sakramen. Sebagai perjanjian ia mempunyai sifat yaitu perkawinan tidak dapat dilangsungkan tanpa persetujuan sebagaimana suatu perjanjian, ditetapkannya ketentuan-ketentuan yang mengatur pelanggaran. Dari segi sosialnya antara lain, Hukum Islam menempatkan perempuan pada suatu kedudukan sosial yang tinggi sesudah perkawinan, pembatasan kebiasaan poligami. Dari segi keagamaan, perkawinan diakui sebagai dasar masyarakat, ia adalah suatu perjanjian sekaligus persetujuan suci. Perkawinan sementara dilarang karena perkawinan merupakan suatu lembaga yang mengangkat tinggi derajat manusia dan suatu cara melanjutkan kehidupan umat manusia, suami istri diperintahkan dengan tegas untuk saling menghormati dan cinta mencintai.

Putusnya perkawinan karena kehendak suami atau istri atau kehendak keduanya karena tidak adanya kerukunan, disebut istilah perceraian, yang bersumber dari tidak dilaksanakannya hak-hak dan kewajiban sebagai suami istri. sebagaimana seharusnya menurut hukum perkawinan yang berlaku. Pergaulan antara suami dan istri yang tidak saling menghormati, tidak saling menjaga rahasia masingmasing, keadaan rumah tangga yang tidak aman dan tentram, serta terjadi silang sengketa atau pertentangan pendapat yang sangat prinsip adalah faktor-faktor penyebab perceraian. 
Keretakan rumah tangga yang mungkin terjadi karena hal-hal yang sepele mulai dari ketidakharmonisan hubungan, ketidakpercayaaan antara suami istri sehingga menimbulkan perceraian. Konflik-konflik dalam perkawinan yang menyebabkan keretakan hubungan suami-istri atau bahkan menyebabkan perceraian,biasanya bersumberkan pada kepribadian suami istri dan hal-hal yang erat kaitannya dengan perkawinan. (Susanto, 2008) Sehingga salah satu permasalahan setelah perceraian biasanya pasangan suami istri mempersoalkan hartanya, harta bersama (Gonogini), harta bawaan masing-masing. konflik pembagian harta gono gini bagi pasangan suami istri berisko kalau pembagiannya tidak efektif dan adil.

Secara Yuridis Normatif Harta bersama (Gono gini) diatur di dalam UUD No 1 Tahun 1974 tentang perkawinan Pasal 35 di atur. a. Harta benda yang diperoleh selama perkawinan, menjadi harta bersama. b. Harta bawaan dan masing-masing suami dan isteri dan harta benda yang diperoleh masing-masing sebagai hadiah atau warisan, adalah dibawah penguasaan masing-masing sepanjang para pihak tidak menentukan lain. Pasal 36 Undang-Undang Perkawinan menyatakan bahwa mengenai harta bersama, suami dan istri dapat bertindak atas persetujuan kedua belah pihak, dan harta bawaan masing-masing suami dan istri mempunyai hak sepenuhnya untuk melakukan perbuatan hukum mengenai harta bendanya. Pasal 37 Undang-Undang Perkawinan menyatakan bahwa bila perkawinan putus karena perceraian harta bersama diatur menurut hukumnya masing-masing. Jika dilihat maka Pasal 37 Undang-Undang Perkawinan dan penjelasannya, tidak memberikan keseragaman hukum positif tentang bagaimana penyelesaian dan penetapan harta bersama apabila terjadi perceraian.(UU Perkawinan No 1 Tahun 1974 tentang Harta Bersama)

Sedangankan Kompilasi Hukum Islam Pasal 85 menegaskan "adanya harta bersama dalam perkawinan itu tidak menutup kemugkinan adanya harta milik masing-masing suami atau isteri" dan Pasal 86 sebagai berikut: a) Pada dasarnya tidak ada percampuran antara harta suami dan harta isteri karena perkawinan. b) Harta isteri tetap menjadi hak isteri dan dikuasai penuh olehnya, demikian juga harta suami tetap menjadi hak suami dan dikuasai penuh olehnya. Pasal 97 Janda atau duda cerai masing-masing berhak seperdua dari harta bersama sepanjang tidak ditentukan lain dalam perjanjian 
perkawinan. (Kompilasi Hukum Islam tentang Harta bersama) Jika di cermati juga di Kompilasi Hukum Islam (KHI) Pasal 86 dan 97 tentang Harta Bersama tidak memberikan keseragam dalam Hukum Islam tentang penyelesaian harta bersama apabila terjadi perceraian, hal ini tentu menjadi problem sosial hukum. jika penyelesaian dan penetapan Harta bersama tersebut tidak efektif dan adil dalam pembagiannyanya. Maka, rentan konflik antara pasangan suami istri kemungkinan bisa terjadi.

\section{Metode Penelitian}

Metode penelitian ini menggunakan Penelitian Yuridis Normatif, penelitian ini bersifat Preskriptif (Soerjono Soekanto, 198:143). menguraikan atau menjelaskan Peraturan perundangundangan No 1 tahun 1974 tentang pekawinan, KHI (Kompilkasi Hukum Islam) tentang Bagaimana Pembagian Harta Gono-Gini. serta mengkaji Peraturan perundang-undangan No 1 tahun 1974 tentang pekawinan serta KHI (Kompilkasi Hukum Islam) tentang Bagaimana impilkasi penyelesaian dan penetapan Pembagian Harta Gono-Gini dalam persfektif Yuridis Sosiologis. Penelitian ini menggunakan Pendekatan konsep untuk memahami tentang Penyelesaian Pembagian Harta Gono Gini menurut Peraturan Perundangundangan.

\section{Pembahasan}

\section{Pembagian Harta Gono Gini Pasca Perceraian dalam Persfektif Hukum Islam}

Pada dasarnya Hukum Islam tidak mengenal istilah percampuran harta kekayaan antara suami atau istri karena pernikahan. Harta kekayaan istri tetap menjadi milik istri dan dikuasai penuh olehnya, demikian pula harta kekayaan suami menjadi milik suami dan dikuasai penuh oleh suami. (Ismuha, 1978: 38). Karena harta kekayaan merupakan kebutuhan pokok, memang tidak mudah untuk digabungkan. sehingga untuk memiliki dan menguasai harta kekayaan mutlak kewajiban bagi masing-masing pasangan suami istri.

Menurut Ahmad Azhar Basyir, istri secara langsung juga berhak terhadap harta tersebut. Berdasarkan hal tersebut, maka sesungguhnya masalah harta gono-gini atau harta bersama tidak 
disinggung secara jelas dan tegas dalam Hukum Islam. Dengan kata lain, masalah harta gono-gini merupakan wilayah Hukum yang belum terpikirkan (ghairu al mufakkar fih) dalam Hukum Islam, oleh karena itu, terbuka bagi ahli Hukum Islam untuk melakukan ijtihad dengan pendekatan qiyas. (As'ad, Abd. Rasyid, 2010: 4).

Menurut Syayuti Thalib, asal usul harta suami istri itu dapat digolongkan pada (tiga) 3 golongan yaitu: a. Harta masing-masing suami atau istri yang didapat sebelum perkawinan adalah harta bawaan atau dapat dimiliki secara sendiri-sendiri; b. Harta yang diperoleh sepanjang perkawinan itu berjalan, tetapi bukan dari usaha mereka melainkan hibah, wasiat atau warisan adalah harta masingmasing; c. Harta yang diperoleh sepanjang perkawinan, baik usaha sendiri suami atau istri maupun bersama-sama merupakan harta pencarian atau harta bersama. (Thalib Sayuti, 1974: 30). Ahmad Azhar Basyir dalam bukunya Hukum Perkawinan Islam menyatakan, Hukum Islam memberi hak kepada masing-masing pasangan, baik suami atau istri untuk memiliki harta benda secara perseorangan yang tidak bisa diganggu oleh masing-masing pihak. Suami yang menerima pemberian, warisan dan sebagainya, berhak menguasai sepenuhnya harta yang diterimanya itu, tanpa adanya campur tangan istrinya. (Ahmad Azhar Basyir, 2000:32).

Harta Gono Gini yang didefinisikan sebagai harta yang dihasilkan oleh pasangan suami istri selama perkawinan berlangsung, maka harta gono gini dapat dikategorikan sebagai Syirkah Mufawadhah atau juga Syirkah Abdan. Syirkah mufawadhah adalah suatu bentuk perkongsian dua belah pihak yang melakukan kegiatan usaha, sedangkan pihak ketiga sebagai pemodal, sedangkan Syirkah Abdan adalah suatu bentuk perkongsian dua pihak atau lebih yang masing-masing, anggotanya hanya melakukan kegiatan usaha, namun tidak memberikan modal. (As'ad, Abd. Rasyid, 2010: 45).

Syirkah (Perkongsian) dapat diadakan dengan mengadakan perjanjian Syirkah secara tertulis atau ucapan sebelum atau sesudah berlangsungnya akad nikah dalam suatu perkawinan, baik untuk harta bawaan maupun harta yang diperoleh selama perkawinan tapi bukan atas usaha mereka maupun harta pencaharian. (Thalib, Sayuti, 1974: 32). Sebagaimana dijelaskan dalam al-Qur'an : Artinya : bagi orang laki-laki ada bahagian daripada yang mereka usahakan, dan bagi para wanita pun ada bahagian dari apa yang mereka usahakan, dan 
mohonlah kepada allah sebagian dari karunianya, sesungguhnya allah maha mengetahui segala sesuatu. (Q.S an-Nisa. Ayat. 32)

Menurut penjelasan ayat di atas bahwa jelas laki-laki apa yang mereka usahakan, begitu sebaliknya perempuan apa yang mereka usahakan. Artinya harta kekayaan apa yang mereka usahakan tidak berpindah kepemilikan kepada orang lain, termasuk istri.

Hadist Rosululah :

Artinya : Aisyah berkata, Hindun binti Utbah istri Abu Sufyan masuk menemui Rasulullah $S A W$ dan berkata : Ya Rasulullah, Sesungguhnya Abu Sufyan adalah seorang laki-laki yang kikir. Dia tidak memberikan saya nafkah yang cukup untuk saya dan anakanakku selain dari apa yang saya ambil dari sebagian hartanya tanpa sepengetahuannya. Apakah saya berdosa karena perbuatan itu? Rasulullah SAW menjawab, "ambillah sebagian hartanya dengan jalan yang ma'ruf secukupnya. (Muttafaq Alaihi).

Hadist tersebut menjelaskan tentang seorang istri yang mempunyai suami yang kikir, yang menahan harta miliknya dan semua pendapatannya kecuali sedikit saja untuk diberikan kepada istri dan anak-anaknya. Pemberian yang sedikit ini tentu saja tidak mencukupi sehingga sang istri merasa harus mengambil kekurangan itu dari harta milik suaminya tanpa izin, karena jika meminta izin pasti tidak akan diberikan. Rasulullah SAW mengizinkan sang istri mengambil harta suaminya tanpa izin sebatas memenuhi kebutuhannya dengan patut dan tidak untuk bersenang-senang dan berlebihan.

Dari Hadist tersebut kita dapat melihat bahwa harta yang dimiliki suami dan juga pendapatannya adalah tetap milik suami. Apabila istri memiliki bagian dalam harta tersebut, tentu saja sang istri memiliki hak untuk mengambil harta bagiannya dan sang suami tidak dapat menghalanginya, apalagi hal itu dilakukan untuk memenuhi kebutuhannya. Hak istri dalam harta suami adalah sebatas nafkah yang wajar untuk kebutuhannya dan lebih dari itu dia tidak boleh mengambilnya kecuali sang suami berkenan.

Dalam Kompilasi Hukum Islam Pasal 85 menegaskan "adanya harta bersama dalam perkawinan itu tidak menutup kemugkinan adanya harta milik masing-masing suami atau isteri" dan Pasal 86 sebagai berikut: a) Pada dasarnya tidak ada percampuran antara harta suami dan harta isteri karena perkawinan. b) Harta isteri tetap 
menjadi hak isteri dan dikuasai penuh olehnya, demikian juga harta suami tetap menjadi hak suami dan dikuasai penuh olehnya. Pasal 97 Janda atau duda cerai masing-masing berhak seperdua dari harta bersama sepanjang tidak ditentukan lain dalam perjanjian perkawinan.

Secara garis besar di dalam Hukum Islam Harta Gono Gini atau Harta Bersama tidak di singgung secara tegas, akan tetapi di dalam Komplikasi Hukum Islam diatur bahwa harta Gono Gini atau harta bersama masing-masing berhak untuk mendapatkan harta seperdua dari harta bersama sepanjang pihak tidak menentukan perjanjian perkawinan. Oleh karena itu upaya bagi pasangan suami isteri untuk membuat perjanjian Harta bersama dalam perkawinan, jika terjadi perceraian surat perjanjian Harta bersama menjadi alat buktinya. Sesuai dengan Inpres Nomor 1 Tahun 1974 Tentang Kompilasi Hukum Islam pasal 47 menyatakan: "Pada waktu atau sebelum perkawinan dilangsungkan kedua calon mempelai dapat membuat perjanjian tertulis yang disahkan Pegawai Pencatat Nikah mengenai kedudukan harta dalam perkawinan", a. Perjanjian tersebut dalam ayat (1) dapat meliputi percampuran harta pribadi dan pemisahan harta pencaharian masing-masing sepanjang hal itu tidak bertentangan dengan hukum Islam. $b$. Di samping ketentuan dalam ayat (1) dan (2) di atas, boleh juga isi perjanjian itu menetapkan kewenangan masing-masing untuk mengadakan ikatan hipotik atas harta pribadi dan Harta Bersama atau harta syarikat. Ketentuan Kompilasi Hukum Islam tersebut antara lain menggariskan bahwa :

a. Dalam perkawinan terdapat harta bersama, disamping harta pribadi masing-masing suami istri. Harta pribadi tersebut sepenuhnya berada dalam penguasaan masing-masing suami/istri, dan bagi masing-masingnya itu berhak untuk melakukan tindakan hukum terhadap harta dimaksud. Suami, sesuai dengan fungsinya, bertanggungjawab untuk menjaga harta bersama, harta istri dan hartanya sendiri. Demikian juga istri, sesuai dengan fungsinya, turut bertanggung jawab untuk menjaga harta bersama dan harta suami yang ada padanya.

b. Harta bersama dapat berupa benda berwujud dan tidak berwujud. Harta bersama yang berwujud meliputi benda tidak bergerak, benda bergerak dan surat-surat berharga. Sedang harta bersama yang tidak berwujud dapat berupa hak dan kewajiban. 
c. Harta bersama dapat dijadikan sebagai jaminan oleh suami atas persetujuan istrinya. Demikian juga sebaliknya, harta bersama dapat dijadikan jaminan oleh istri atas persetujuan suaminya.

d. Tanpa persetujuan istri, suami tidak diperbolehkan menjual, membebani atau memindah tangankan harta bersama. Demikian juga sebaliknya, istri tidak diperbolehkan menjual, membebani atau memindah tangankan harta bersama tanpa persetujuan suaminya. Pertanggung jawaban terhadap hutang pribadi suami/istri dibebankan pada harta masing-masing, sedangkan pertanggung jawaban terhadap hutang yang diperlukan untuk kepentingan keluarga, dibebankan pada harta bersama. Bila harta bersama tidak mencukupi, pertanggung jawabannya dibebankan kepada harta istri.

e. Harta bersama dari perkawinan serial atau poligami, masingmasing terpisah dan berdiri sendiri, dan untuk itu terhitung mulai saat berlangsungnya akad perkawinan yang kedua, ketiga atau keempat.

f. Suami/istri dapat meminta Pengadilan Agama untuk meletakkan sita jaminan atas harta bersama tanpa adanya permohonan gugatan cerai, apabila salah satu pihak, suami/istri melakukan perbuatan yang merugikan dan membahayakan harta bersama seperti judi, mabuk, boros dan sebagainya. Selama masa sita, dapat dilakukan penjualan atas harta bersama untuk kepentingan keluarga dengan izin Pengadilan Agama.

g. Apabila terjadi cerai mati, maka separuh harta bersama menjadi hak pasangan yang hidup lebih lama. Pembagian harta bersama bagi seorang suami/istri yang istri atau suaminya hilang harus ditangguhkan sampai ada kepastian matinya yang hakiki atau matinya secara hukum atas dasar keputusan Pengadilan Agama. Janda atau duda cerai hidup masing-masing berhak seperdua dari harta bersama sepanjang tidak ditentukan lain dalam perjanjian perkawinan.(Kompilasi Hukum Islam tentang Harta Bersama)

\section{Pembagian Harta Gono Gini Pasca Perceraian dalam Persfektif Hukum Positif}

Faktor terjadinya perceraian yang mungkin terjadi karena halhal yang sepele mulai dari ketidakharmonisan dan ketidakpercayaan antara suami isteri sehingga menimbulkan perceraian. Sehingga setelah terjadinya perceraian biasanya pasangan suami isteri 
mempersoalkan hartanya terutama didalam pembagian harta bersama atau harta Gono Gini. didalam UU No.1 Tahun 1974 yang berbunyi bahwa putusnya suatu perkawinan dapat terjadi karena adanya kematian, perceraian, dan putusnya perkawinan.

Secara Yuridis Normatif Harta Bersama diatur didalam UUD No 1 Tahun 1974 tentang perkawinan Pasal 35 di atur. a. Harta benda yang diperoleh selama perkawinan, menjadi harta bersama. b. Harta bawaan dan masing-masing suami dan isteri dan harta benda yang diperoleh masing-masing sebagai hadiah atau warisan, adalah dibawah penguasaan masing-masing sepanjang para pihak tidak menentukan lain. Pasal 36 Undang-Undang Perkawinan menyatakan bahwa mengenai harta bersama, suami dan istri dapat bertindak atas persetujuan kedua belah pihak, dan harta bawaan masing-masing suami dan istri mempunyai hak sepenuhnya untuk melakukan perbuatan hukum mengenai harta bendanya. Pasal 37 UndangUndang Perkawinan menyatakan bahwa bila perkawinan putus karena perceraian harta bersama diatur menurut hukumnya masingmasing.

Jika dicermati pada pasal 47 UU perkawinan dengan pasal pasal 36 UU perkawinan tidak sesuai tentang bagaimana penyelesaian harta bersama apabila terjadinya perceraian. Jika dilihat Pada Pasal 37 Undang-Undang Perkawinan, maka undang-undang ini memberikan jalan pembagian sebagai berikut: Pertama, Dilakukan berdasarkan Hukum Agama jika Hukum Agama itu merupakan kesadaran hukum yang hidup dalam mengatur tata cara perceraian; Kedua, Aturan pembagiannya akan dilakukan menurut Hukum Adat, jika hukum tersebut merupakan kesadaran hukum yang hidup dalam lingkungan masyarakat yang bersangkutan; Ketiga, atau hukum-hukum lainnya. (Harahap, M. Yahya, 1975:125). Peraturan UU Perkawinan No 1 Tahun 1974 tentang Harta bersama belum efektif dalam penyelesaian dan penetapan pembagiannya, karena tidak dijelaskan batasanbatasan penetapan harta bersama. di samping itu, harta kekayaan yang didapat sepanjang perkawinan inilah yang akan dibagi jika perkawinan itu putus, baik karena perceraian, kematian ataupun putusan pengadilan. Penetapan harta bersama dalam perkawinan sangat penting sebagai penguasaan dan pembagiannya yakni penguasaan terhadap harta bersama dalam hal perkawinan masih berlangsung serta pembagian harta bersama dilakukan ketika terjadi putusnya perkawinan. karena ketentuan harta bersama dalam 
Undang-Undang Perkawinan di atas tidak menyebutkan dari mana atau dari siapa harta itu berasal, sehingga boleh disimpulkan bahwa yang termasuk dalam harta bersama adalah: a. Hasil dan pendapatan suami selama masa perkawinan; b. Hasil dan pendapatan istri selama masa perkawinan; c. Hasil dan pendapatan dari harta pribadi suami maupun istri, sekalipun harta pokoknya tidak termasuk dalam harta bersama, asal semuanya diperoleh selama masa perkawinan. (Satrio J, 1990: 189).

Dalam suatu perkawinan terdapat tiga macam harta kekayaan, yaitu: Pertama, Harta pribadi suami ialah Harta bawaan suami, yaitu yang dibawa sejak sebelum perkawinan, dan Harta yang diperolehnya sebagai hadiah atau warisan. Kedua, Harta pribadi istri ialah: Harta bawaan istri, yaitu yang dibawanya sejak sebelum perkawinan, dan Harta yang diperolehnya sebagai hadiah atau warisan. Ketiga, Harta bersama suami istri ialah harta yang diperoleh baik sendiri-sendiri atau bersama suami-istri selama dalam ikatan perkawinan, tanpa mempersoalkan terdaftar atas nama siapapun. (Mukti, Arto, 1998: 70).

Sayuti Thalib, (Thalib Sayuti,1974). berpendapat bahwa harta bersama dibagi dalam (tiga) kelompok yaitu: Pertama, Harta masing-masing suami atau istri yang didapat sebelum perkawinan adalah harta bawaan atau dapat dimiliki secara sendiri-sendiri. Kedua Harta yang diperoleh sepanjang perkawinan itu berjalan, tetapi bukan dari usaha mereka melainkan hibah, wasiat atau warisan adalah harta masing-masing. Ketiga Harta yang diperoleh sepanjang perkawinan, baik usaha sendiri suami atau istri maupun bersama-sama merupakan harta pencarian atau harta bersama. Hartono Seorjopratikno merinci harta bersama dalam perkawinan sebagai berikut: a. Sejak pelaksanaan perkawinan karena hukum ada kebersamaan harta menyeluruh yang meliputi laba semua benda yang sudah maupun yang belum ada. b. Kebersamaan harta itu pada umumnya meliputi laba semua benda bergerak dan tidak bergerak dari pada suami istri, baik yang sudah ada maupun yang akan ada, dan yang diperoleh mereka secara cuma-cuma c. Dalam hal beban, kebersamaan itu meliputi semua hutang yang dibuat oleh suami istri, baik sebelum maupun sesudah dilangsungkannya perkawinan. d. Termasuk dalam kebersamaan itu semua buah dan hasil yang diperoleh dari harta bersama tersebut. (Hartono Seorjopratikno) 
Berdasarkan KUH Perdata (BW), (KUHPerdata Pasal 119) sejak dilangsungkan perkawinan, maka menurut hukum terjadi harta bersama menyeluruh antara suami istri, sejauh tentang hal itu tidak diadakan ketentuan-ketentuan dalam perjanjian kawin. Harta bersama itu selama perkawinan berjalan tidak boleh ditiadakan atau dirubah dengan suatu persetujuan antara suami istri. Harta bawaan yang merupakan harta pribadi otomatis menjadi harta bersama ketika terjadi perkawinan, sebab adanya harta bersama itu sendiri adalah akibat dari terjadinya suatu perkawinan. Dalam Pasal 140 Ayat 3 menjelaskan, mereka juga berhak untuk membuat perjanjian, bahwa meskipun ada golongan harta bersama, barang-barang tetap, suratsurat pendaftaran dalam buku besar pinjaman-pinjaman negara, suratsurat berharga lainnya dan piutang-piutang yang diperoleh atas nama istri, atau yang selama perkawinan dan pihak istri jatuh ke dalam harta bersama, tidak boleh dipindah tangankan atau dibebani oleh suaminya tanpa persetujuan si istri.

Dalam kitab KUHP Pasal 119 menjelaskan : sejak saat dilangsungkannya perkawinan, maka menurut hukum terjadi harta bersama menyeluruh antara suami isteri, sejauh hal itu tidak ditiadakan ketentuan-ketentuan lain dalam perjanjian perkawinan. Harta bersama itu, selama perkawinan berjalan, tidak boleh ditiadakan atau diubah dengan suatu persetujuan antara suami isteri. KUHP Pasal 122 menjelaskan : semua penghasilan dan pendapatan, begitu pula semua keuntungan-keuntungan dan kerugian-kerugian yang diperoleh selama perkawinnan, juga menjadi keuntungan dan kerugian harta bersama itu. Pasal 124 KUHPerdata, suamilah yang berhak mengurus harta bersama, termasuk berwenang melakukan berbagai perbuatan terhadap harta tersebut. isi Pasal 124 KUHPerdata tersebut antara lain adalah: pertama, hanya suami saja yang boleh mengurus harta bersama itu, kedua, dia boleh menjualnya, memindah tangankan dan membebaninya tanpa bantuan istrinya. kecuali dalam hal yang diatur dalam Pasal 140. ketiga, dia tidak boleh memberikan harta bersama sebagai hibah antara mereka yang sama-sama masih hidup, baik barang-barang tak bergerak maupun keseluruhannya atau suatu bagian atau jumlah yang tertentu dan barang-barang bergerak, bila bukan kepada anak-anak yang lahir dan perkawinan mereka, untuk memberi suatu kedudukan. keempat, bahkan dia tidak boleh menetapkan ketentuan dengan cara hibah mengenai sesuatu barang yang khusus, bila dia memperuntukkan untuk dirinya hak pakai hasil 
dari barang itu. Hukum adalah suatu perintah yang berbentuk peraturan perundang-undangan yang di buat secara formal oleh lembaga yang di beri kewenangan oleh Negara. M. Yahya Harahap, pikiran pembuat undang-undang mengenai penyelesaian pembagian harta bersama diserahkan kepada kehendak dan kesadaran masyarakat dan hakim yang akan mencari dan menemukan dalam kesadaran hukum masyarakat untuk dituangkan sebagai hukum objektif. (Harahap, M. Yahya, 1975). Pendapat kedua ia menyatakan pembuat undang-undang tidak usah ditentukan one way traffic sebagai satu saluran hukum positif sebab berdasarkan kenyataan kesadaran hukum yang hidup dalam masyarakat, tentang hal ini masih menuju perkembangan bentuk yang lebih serasi sebagai akibat meluasnya interaksi antara segala unsur kesadaran yang sedang dialami oleh bangsa Indonesia.

Berdasarkan penggolongan jenis-jenis harta tersebut maka sebagai konsekuensinya terdapat 2 (dua) macam penggolongan hak milik terhadap harta yaitu:

a. Adanya hak milik secara kolektif atau bersama khusus mengenai harta yang digolongkan sebagai harta hasil dari mata pencaharian, pengaturannya adalah hak kepemilikan terhadap harta tersebut dimiliki secara bersama-sama oleh pasangan suami- istri. Dengan adanya hak kepemilikan secara kolektif ini tentunya wewenang dan tanggung jawab terhadap harta bersama tersebut berada di tangan suami dan istri. Apabila suami hendak menggunakan harta bersama maka si suami harus mendapat persetujuan dari istri, demikian juga sebaliknya.

b. Adanya hak milik pribadi secara terpisah Pada harta yang digolongkan sebagai jenis harta yang kedua yaitu harta bawaan dan jenis harta ketiga yaitu harta yang diperoleh dalam perkawinan tetapi tidak berasal dari mata pencaharian, terhadap keduanya pengaturan terhadap hak milik pada dasarnya dilakukan secara terpisah, yaitu masing-masing suami- istri mempunyai hak milik secara terpisah terhadap harta yang dimilikinya sebelum terjadinya perkawinan. 


\section{Analisis Pembagian Harta Gono Gini dalam Persfektif Yuridis Sosial}

Hukum akan menjadi efektif jika tujuan keberadaan dan penerapannya dapat mencegah perbuatan-perbuatan yang tidak diinginkan dapat menghilangkan kekacauan. Hukum yang efektif secara umum dapat membuat apa yang dirancang dapat diwujudkan. Di dalam UUD No 1 Tahun 1974 tentang perkawinan Pasal 35 di atur. a. Harta benda yang diperoleh selama perkawinan, menjadi harta bersama. b. Harta bawaan dan masing-masing suami dan isteri dan harta benda yang diperoleh masing-masing sebagai hadiah atau warisan, adalah dibawah penguasaan masing-masing sepanjang para pihak tidak menentukan lain. Pasal 36 Undang-Undang Perkawinan menyatakan bahwa mengenai harta bersama, suami dan istri dapat bertindak atas persetujuan kedua belah pihak, dan harta bawaan masing-masing suami dan istri mempunyai hak sepenuhnya untuk melakukan perbuatan hukum mengenai harta bendanya. Pasal 37 Undang-Undang Perkawinan menyatakan bahwa bila perkawinan putus karena perceraian harta bersama diatur menurut hukumnya masing-masing.

Jika dilihat maka Pasal 37 Undang-Undang Perkawinan dan penjelasannya, tidak memberikan keseragaman hukum positif tentang bagaimana penyelesaian harta bersama apabila terjadi perceraian. Karena antara pasal 36 dan 37 tidak selaras dalam menetapkan konsep harta bersama. sehingga peraturan UU tersebut menjadi timpang dalam merumuskan penetapan harta bersama. Selain itu, Kompilasi Hukum Islam Pasal 85 menegaskan "adanya harta bersama dalam perkawinan itu tidak menutup kemugkinan adanya harta milik masing-masing suami atau isteri" dan Pasal 86 sebagai berikut: a) Pada dasarnya tidak ada percampuran antara harta suami dan harta isteri karena perkawinan. b) Harta isteri tetap menjadi hak isteri dan dikuasai penuh olehnya, demikian juga harta suami tetap menjadi hak suami dan dikuasai penuh olehnya. Pasal 97 Janda atau duda cerai masing-masing berhak seperdua dari harta bersama sepanjang tidak ditentukan lain dalam perjanjian perkawinan. Jika dicermati antara pasal 86 dan 97 juga tidak seragam dalam penyelesaian dan penetapan harta bersama. Sehingga, Secara Yuridis UU tersebut belum efektif dalam penyelasaian dan penerapannya, karena pada dasarnya undang-undang merupakan aturan hukum yang mengikat. Hukum sebagai perwujudan nilai-nilai 
mengandung arti, bahwa kehadirannya untuk melindungi dan memajukan nilai-nilai yang dijunjung tinggi oleh masyarakat. Eksistensi dan kemampuan hukum lalu diukur seberapa jauh ia telah mewujudkan keadilan tersebut. Dengan demikian, moral keadilan telah menjadi dasar untuk mensahkan kehadiran dan bekerjanya hukum. (Rahardjo2006: 66).

Oleh Karena itu, keadilan merupakan suatu keharusan. Hukum itu harus adil, sedangkan adil itu sendiri bersifat subjektif, tidak bisa disama ratakan terhadap semua orang. Keadilan itu sesuatu yang abstrak, subyektif karena keadilan bagaimanapun menyangkut nilai etis yang dianut masing-masing individu. Selain itu, Bahwa faktorfaktor yang menghambat efektivitas penegakan hukum tidak hanya terletak pada sikap mental aparatur penegak hukum (hakim, jaksa, polisi dan penasihat hukum) akan tetapi juga terletak pada faktor sosialisasi hukum yang sering diabaikan. Bustanul Arifin mengatakan bahwa dalam negara yang berdasarkan hukum, berlaku efektifnya sebuah hukum apabila didukung oeh tiga pilar, yaitu: a. Lembaga atau penegak hukum yang berwibawa dapat diandalkan $b$. Peraturan hukum yang jelas sistematis. c. Kesadaran hukum masyarakat tinggi. (Bustanul Arifin, 2011: 10)

Perubahan hukum dan perubahan masyarakat, ada dua macam perubahan hukum yaitu;

a. Perubahan hukum yang bersifat ratifikasi. Dalam hal ini sebenarnya masyarakat sudah terlebih dahulu berubah dan sudah mempraktikkan perubahan dimaksud kemudian diubahlah hukum untuk disesuaikan dengan perubahan yang sudah terlebih dahulu terjadi dalam mayarakat. Akan tetapi perlu diketahui bahwa dalam hal ini tidak serta-merta terjadi perubahan hukum jika terjadi perubahan dalam masyarakat. Yang lebih sering ialah hukum sulit merespons perubahan yang terjadi dimasyarakat. Sebab hakikinya hukum itu super konservatif, dan kalaupun berkembang dia berkembang mengikuti iramanya sendiri, berputar diorbitnya sendiri dengan logikanya sendirir dijalan yang sunyi. Perubahan masyarakat yang menyebabkan perubahan hukum ini sering terjadi perubahan dalam bentuk perubahan undang-undang yang ada. Tetapi sekali-kali juga perubahan dalam Yurisprudensi yang bersifat menggebrak.

b. Perubahan hukum yang bersifat proaktif. Dalam hal ini masyarakat belum mempraktikkan perubahan tersebut, tetapi 
sudah ada ide-ide yang berkembang terhadap perubahan dimaksud. Kemudian sebelum masyarakat mempraktikkan perubahan ynag dimaksud, hukum sudah terlebih dahulu diubah, sehingga dapat mempercepat praktik perubahan masyarakat tersebut. dalam hal ini, berlakulah ungkapan "hukum sebagai sarana rekayasa masyarakat" ( lawastool social enginerring ). (Fuad, 52-55)

\section{Simpulan}

Dalam Hukum Islam memang tidak disinggung secara tegas tentang pembagian Harta Bersama, akan tetapi di dalam Peraturan KHI diatur tentang harta bersama. Dalam KHI pasal 85 penjelasanya multitafsir, terkait pembagian Harta Bersama, dijelaskan bahwa harta bersama tidak ada percampuran dalam perkawinan, akan tetapi didalam pasal 97 penjelasanya untuk pembagain harta gono gini dibagi menjadi dua. Peraturan UU Perkawinan No 1 Tahun 1974 tentang Harta Bersama tidak mengatur batasan pembagian harta bersama apabila terjadi perceraian. Secara Yuridis Sosial UU perkawinan No 1 Tahun 1974 pasal 37 tidak efektif dan adil dalam penyelesaian dan penetapan harta bersama (Gono-Gini), oleh karena itu, Pemerintah untuk merivisi UU Perkawinan No 1 tahun 1974 Pasal 37 tentang Harta bersama agar mendapat kepastian Hukum dan kejelasan mengenai batasan pembagian Harta bersama. 


\section{DAFTAR PUSTAKA}

Abd. Rasyid, As'ad. 2010. Gono-Gini dalam Perspektif Hukum Islam, Jurnal Pengadilan Agama.

Arifin, Bustanul. 2011. Efektivitas Undang-Undang Monrey Loundering, Badan Pembinaan Hukum Nasional, Kementrian Hukum dan HAM RI, Jurnal, Jakarta.

Arto, Mukti. 1998. Praktek Perkara Perdata pada Pengadilan Agama, Pustaka Pelajar: Yogyakarta.

Basyir, Ahmad Azhar. 2000. Hukum Perkawinan Islam, UII Press: Yogyakarta.

Hilman, Hadikusuma. 2007. Hukum Perkawinan Indonesia Menurut Perundangan, Hukum Adat, Hukum Agama, Mandar Maju: Bandung.

Ismuha. 1978. Pencaharian Bersama Suami Istri di Indonesia, ce ke 2, Bulan Bintang: Jakarta.

J, Satrio. 1990. Hukum Harta Perkawinan, Cipta Aditya Bakti: Bandung.

Kitab Undang-Undang Hukum Perdata, (KUHAPerdata).

Kompilasi Hukum Islam, (KHI).

M. Yahya, Harahap. 1975. Pembahasan Hukum Perkawinan Nasional Berdasarkan UndangUndang Nomor 1 Tahun 1974, Peraturan Pemerintah Nomor 9 Tahun 1974, Zahir Trading: Medan.

Rahardjo,. 2006. Ilmu Hukum, Citra Aditya Bakti: Bandung.

Sayuti, Thalib. 1974. Hukum Kekeluargaan Indonesia, Yayasan Penerbit UI: Jakarta. 
Soekanto, Soerjono. 1981. Pengantar Penelitian Hukum, UI Press: Jakarta.

Tolib, Setiady. 2008. Intisari Hukum Adat Indonesia dalam Kajian Kepustakaan, Alfabeta: Bandung.

Undang-Undang Nomor 1 Tahun 1974 tentang Perkawinan.

Wignjodipoero, Soerojo. 1995. Pengantar dan AsasAsas Hukum Adat, Gunung Agung Press: Jakarta. 